\title{
The Great Ice Storm of 1998
}

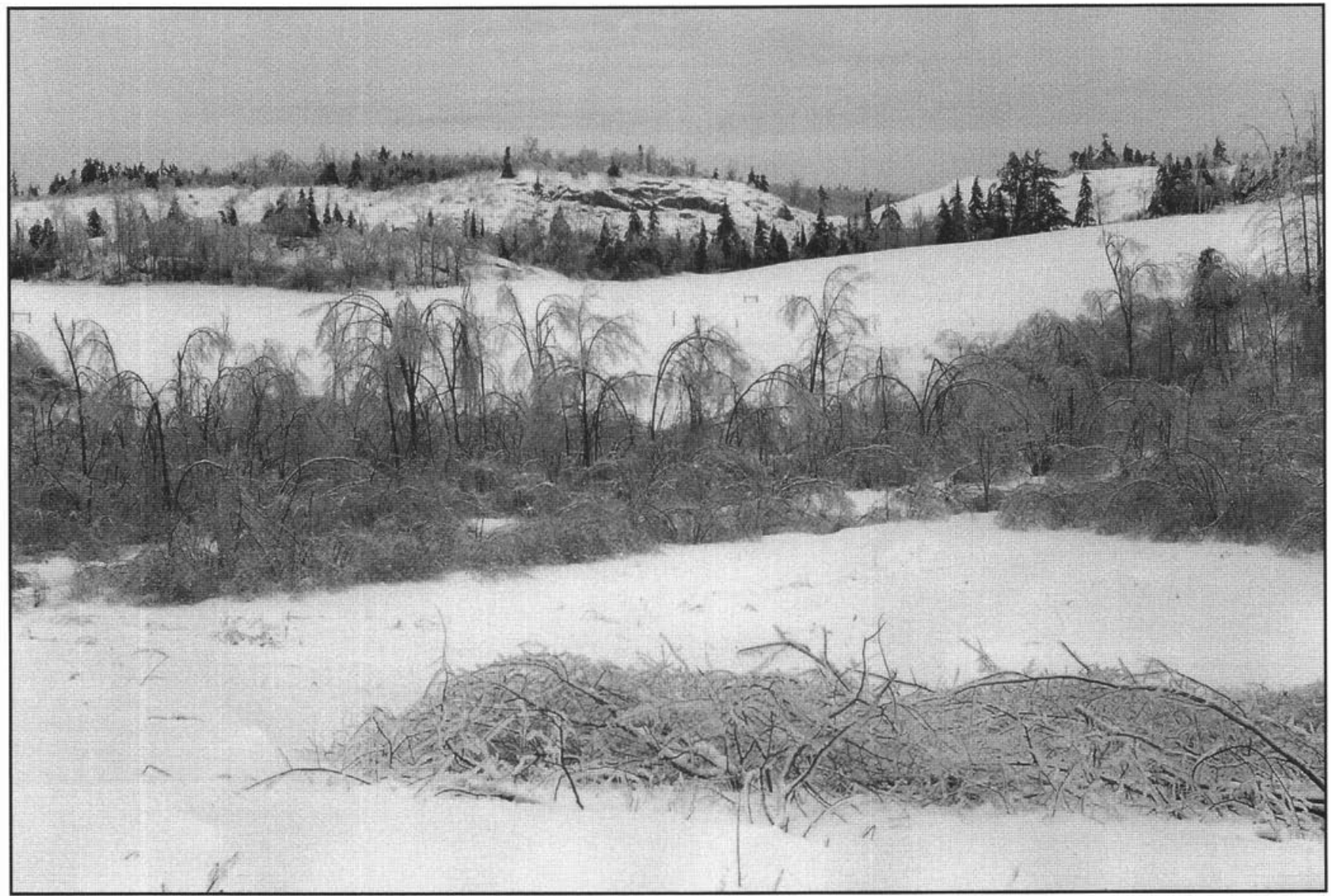

Photo by Drew Gragg. Reproduced with permission of The Ottawa Citizen.

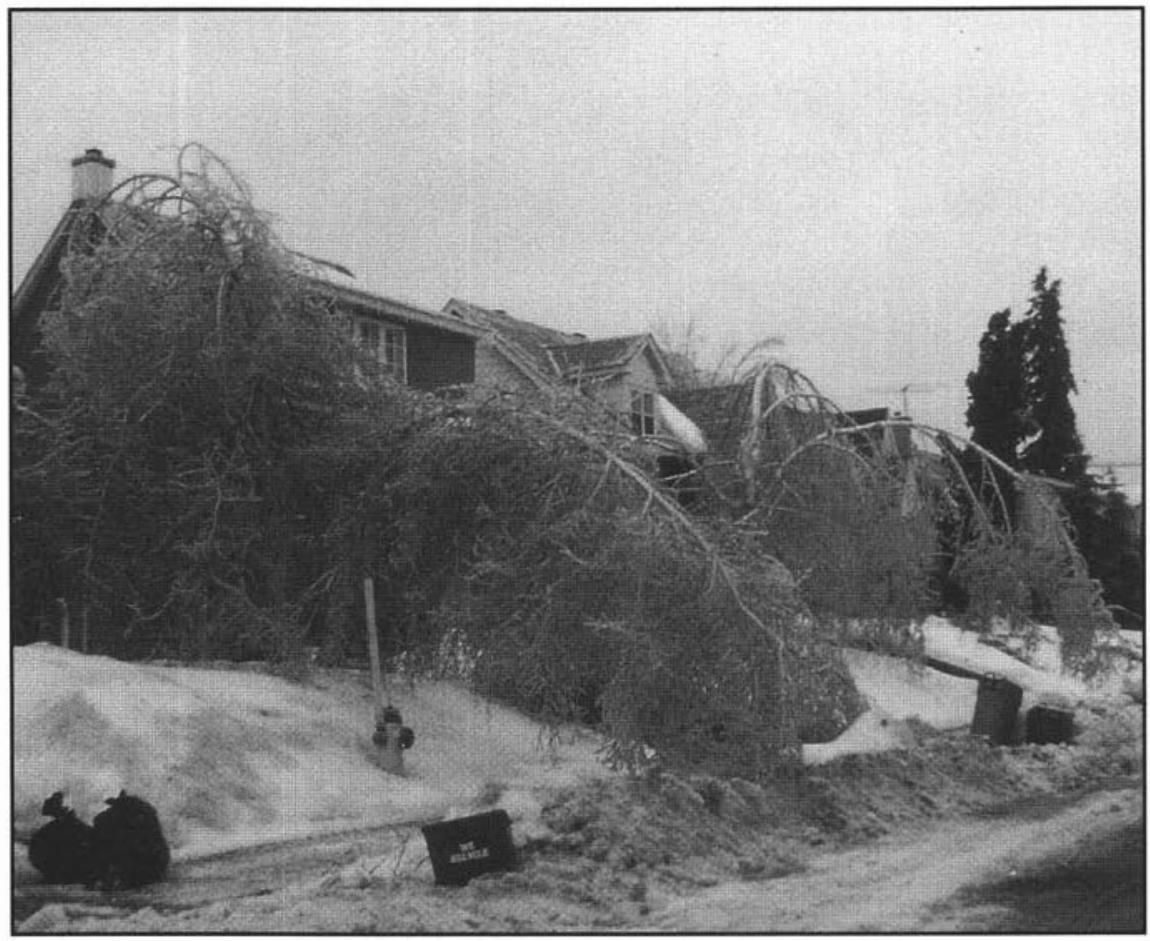

Five days of freezing rain in January 1998 caused chaos, destruction and darkness for millions of citizens in Quebec, Ontario, the Maritimes and the New England States.

In Eastern Canada, the Conference Board of Canada has estimated a loss of some \$1.6 billion, a sum equal to $0.2 \%$ of the country's annual gross domestic product. When all loss impacts are considered, however, this loss and the associated costs may well approach $\$ 4.0$ billion.

This "ice storm of the century", and the devastation to urban and woodlot forest cover, is depicted in words and photographs in the following pages. We are indebted to Brian Smith, City of Ottawa Arborist, for providing many of the photographs.

Photo by Brian Smith, City of Ottawa Arborist.

The Editor 


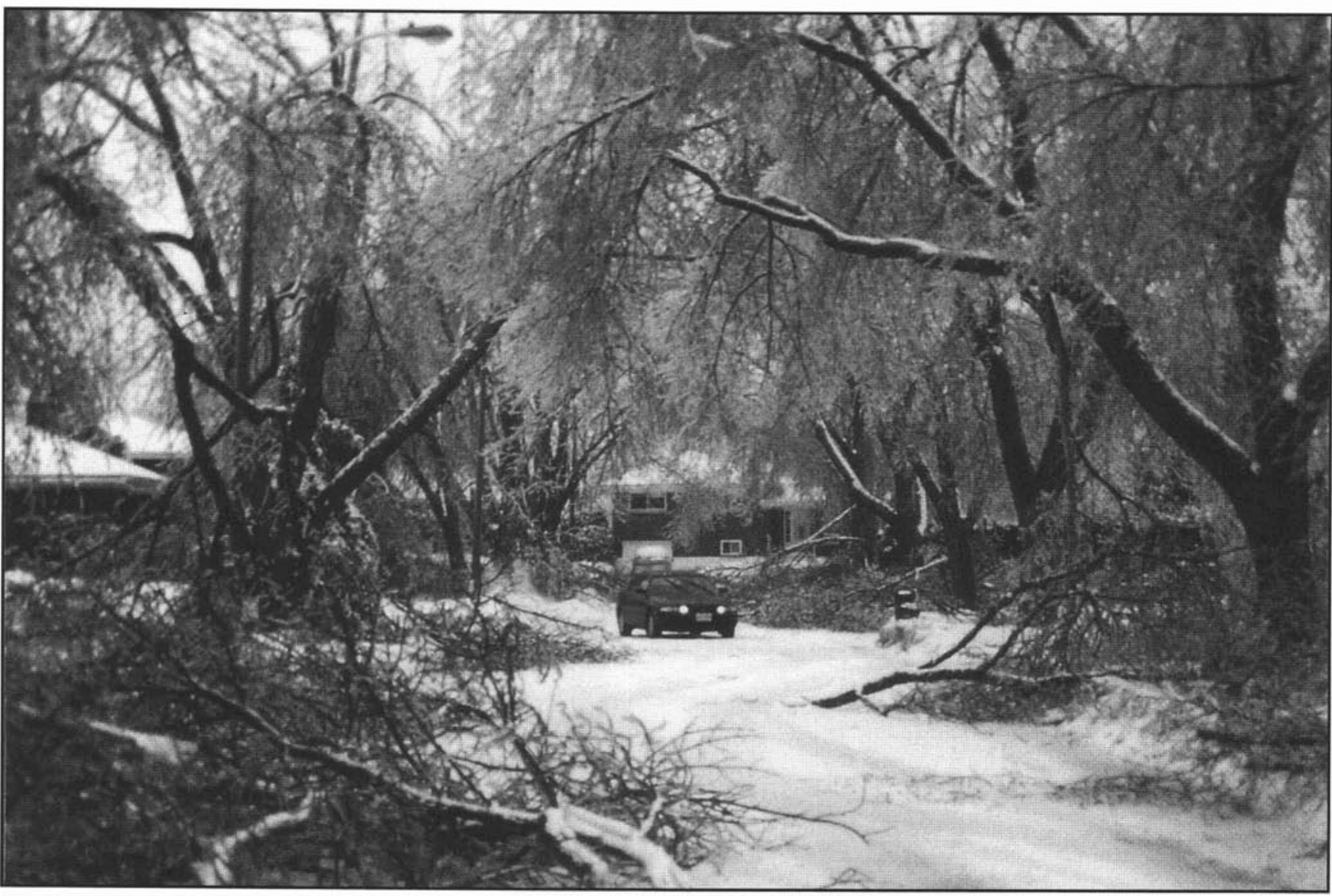

Photo by Brian Smith, City of Ottawa Arborist.

\section{Ottawa Will Never Look the Same}

More than 6,000 trees $-10 \%$ of the trees on municipal property - were so heavily damaged by the ice storm that they will have to be cut down.

"The city will never look the same. It will be 25 or 30 years before the city looks anything like it used to," said Brian Smith, the city's arborist.

There are 60,000 trees on Ottawa roadways, abutting private property or along city boulevards. About $75 \%$ or 45,000 , were damaged by the ice storm that hit Eastern Ontario and Quebec last week. Six thousand of those are beyond saving and the other 39,000 were hit so badly they will need surgery.

"The mature trees took a fair beating and anything over 35 or 40 years old seems to be in dire need," Mr. Smith said.
Photo by Brian Smith, City of Ottawa Arborist.

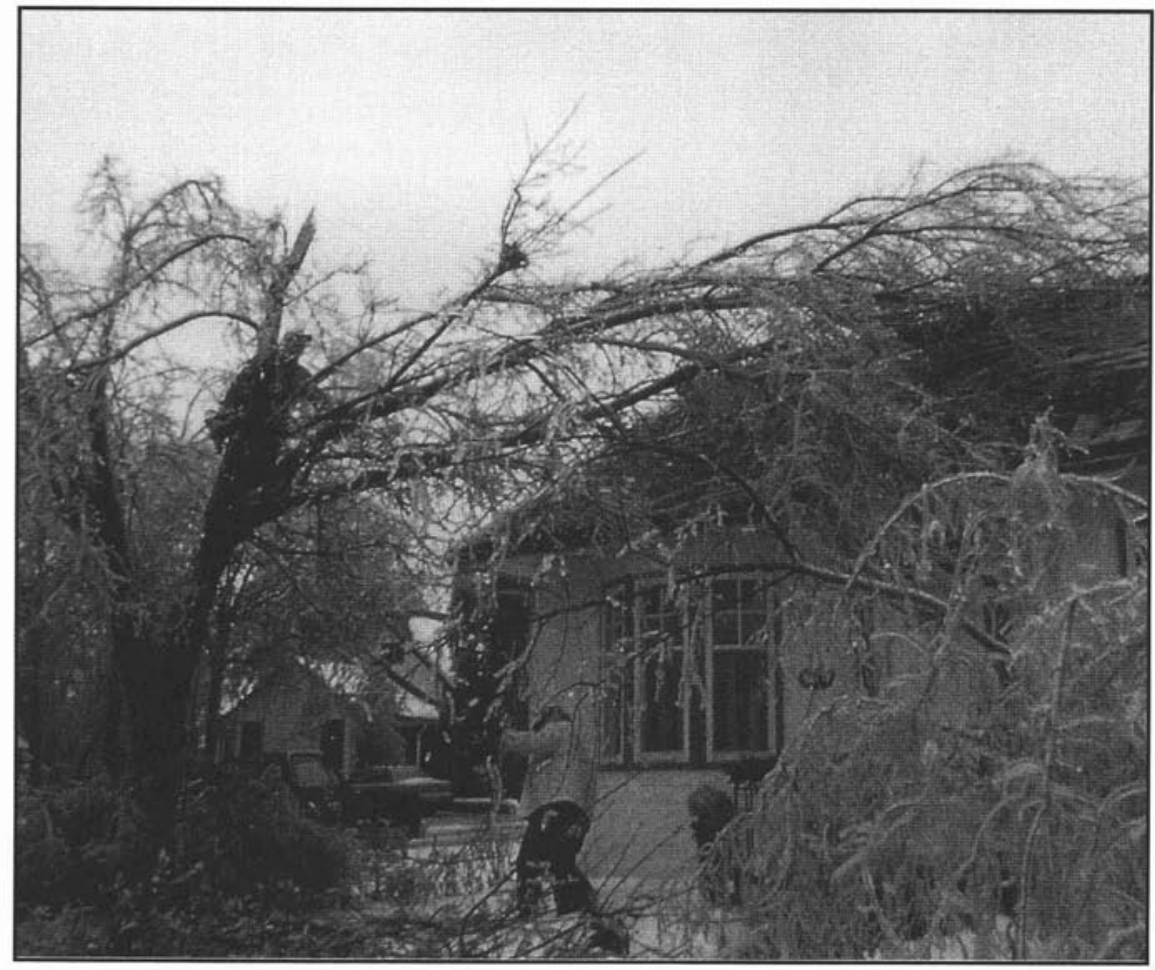




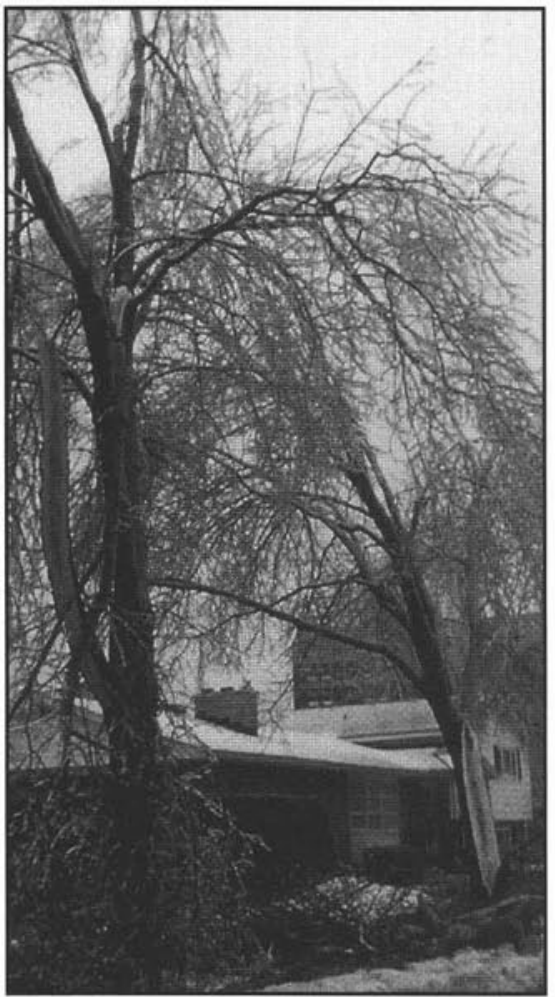

Photo by Brian Smith, City of Ottawa Arborist.

The inventory of damage by city staff does not include trees in city parks, where there are about 120,000 trees, or on private property, nor does it include trees in the Greenbelt, which is owned by the National Capital Commission.

"There is not a single neighbourhood that has been spared from the ravages of the storm," Mr. Watson told about 50 people at a public information meeting in Sandy Hill. Regional Chair Bob Chiarelli also spoke about the damage.

"You could well imagine not only the environmental cost, but the financial cost of attempting to bring the urban forest back to life is going to be tremendous," Mr. Watson said.

It costs the city about $\$ 350$ to buy and plant a tree. The city regularly plants about 500 trees a year and it sells trees for $\$ 30$ to people to plant themselves. Increasing the amount of trees planted this year depends on the amount of extra money the province is willing to give.

Mr. Watson is asking businesses, volunteers, environmental groups and other concerned citizens for ideas on how to rebuild the urban forest.

He said he is looking at expanding the mandate of the Urban Forest Citizens Committee, which deals with tree conservation issues in the city.

One of Ottawa's trademarks is that it is a "green capital city," and it is impor-

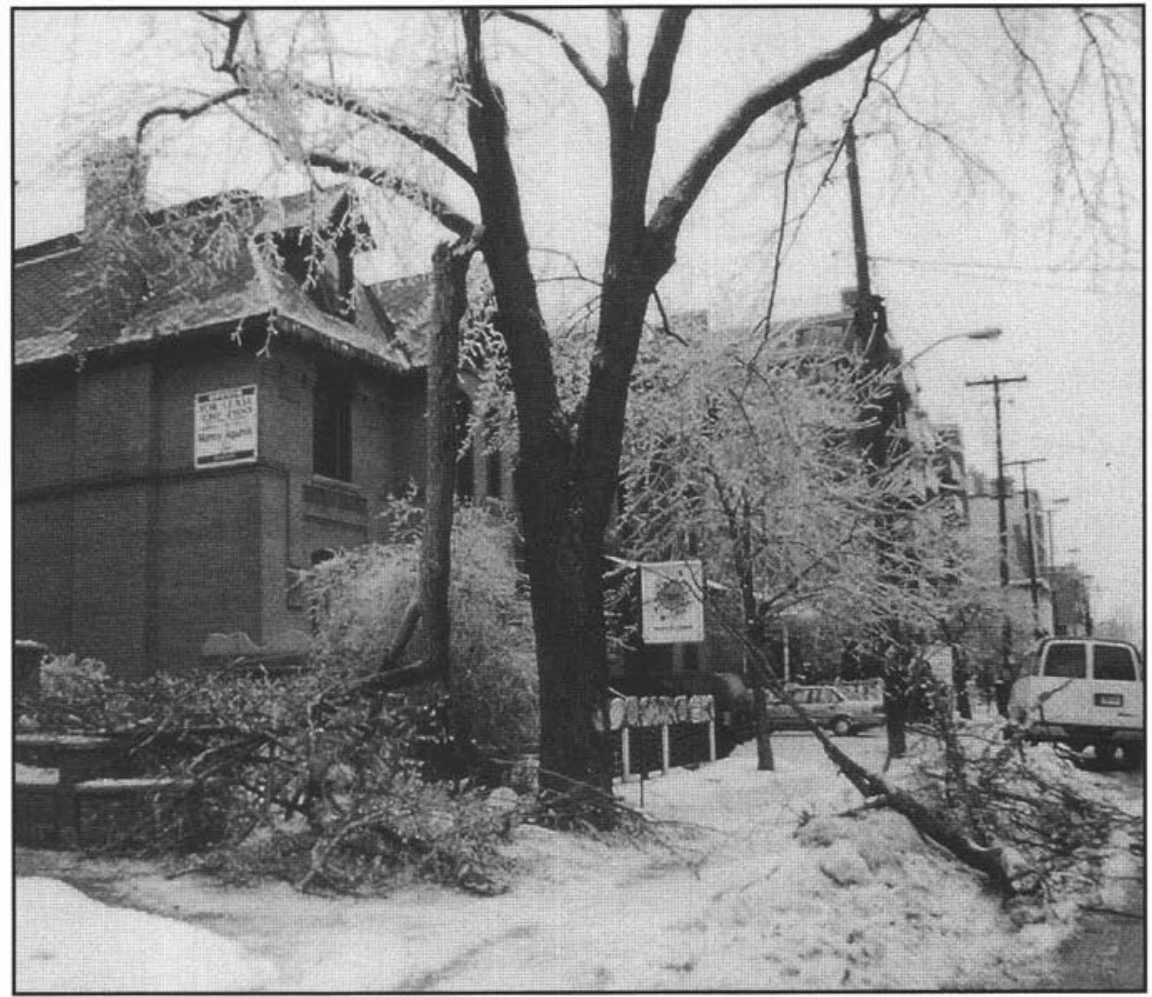

Photo by Brian Smith, City of Ottawa Arborist.

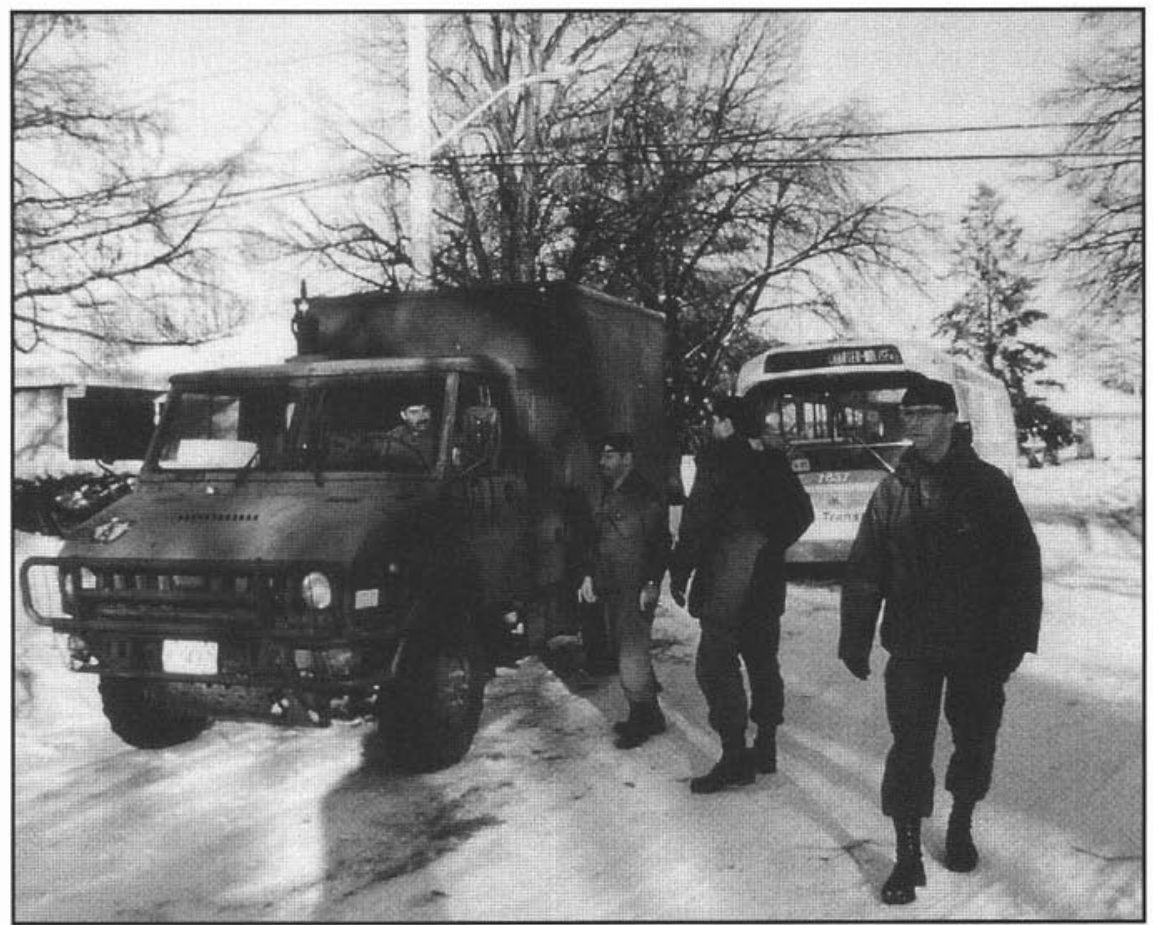

Photo by Brian Smith, City of Ottawa Arborist.

tant to maintain that type of scenery for future generations, he said.

Mr. Smith said many of the trees damaged in the storm were ash, silver maple, Manitoba maple and poplars that lined city roads.

He said city crews' priorities this spring and summer will be clearing branches and fallen trees from city property, school areas and community centres. Most replanting may have to wait until the fall, he said.

The replacement of trees will cost millions. A fund-raising campaign has been launched to assist the costs of replanting.

Ottawa Citizen 


\section{Statement on the Ice Storm Damage by Ontario Association of Landscape Architects, International Society of Aboriculture - Ontario, Ontario Shade Tree Council, and the Ontario Professional Foresters Association}

We are a group of professionals involved in the planning and management of trees in our communities. We would like to appeal to both property owners and public officials to carefully consider the long term issues when assessing the terrible damage to the natural environment caused by the recent ice storm.

Firstly, although people may despair at the damage to area trees, with proper pruning by a qualified arborist, the shape and health of many trees can be restored. Even in instances where the damage appears to be extensive, we encourage people to think beyond the appearance of the trees. If the tree is otherwise structurally sound, the tree still has a significant role to play in our community. Among other things, trees cool the city in summer provide places for birds and animals to live, filter dust and other pollutants and break up prevailing winds. Therefore, even if the tree is misshapen, its contribution to the natural environment should not be underestimated.

Secondly, extensive new planting will be very important to replenish the many trees that were damaged beyond recovery. People may want to consider planting new trees in the same area as declining and misshapen trees. This will allow time for the new trees to grow to a point where they can start to make a definite impact. At that time, declining and misshapen trees can be considered for removal. As can be clearly seen by this ice storm, it is very beneficial to have trees of all sizes and types in the landscape.

Thirdly, people may be hesitant to plant trees near hydro wires and buildings. Proper selection, location and regular maintenance of trees can reduce potential conflicts that may occur and ensure their contribution to our communities. It should be remembered that this was an extreme climatic event, and an uncommon occurrence.

When assessing the damage caused by this recent storm, we encourage public officials to consider not only real property damage and personal loss, but the devastation to the vegetation which makes up the "green infrastructure" of our communities. Trees in cities, towns, and along our roadways are public assets that have real economic, social and envi-
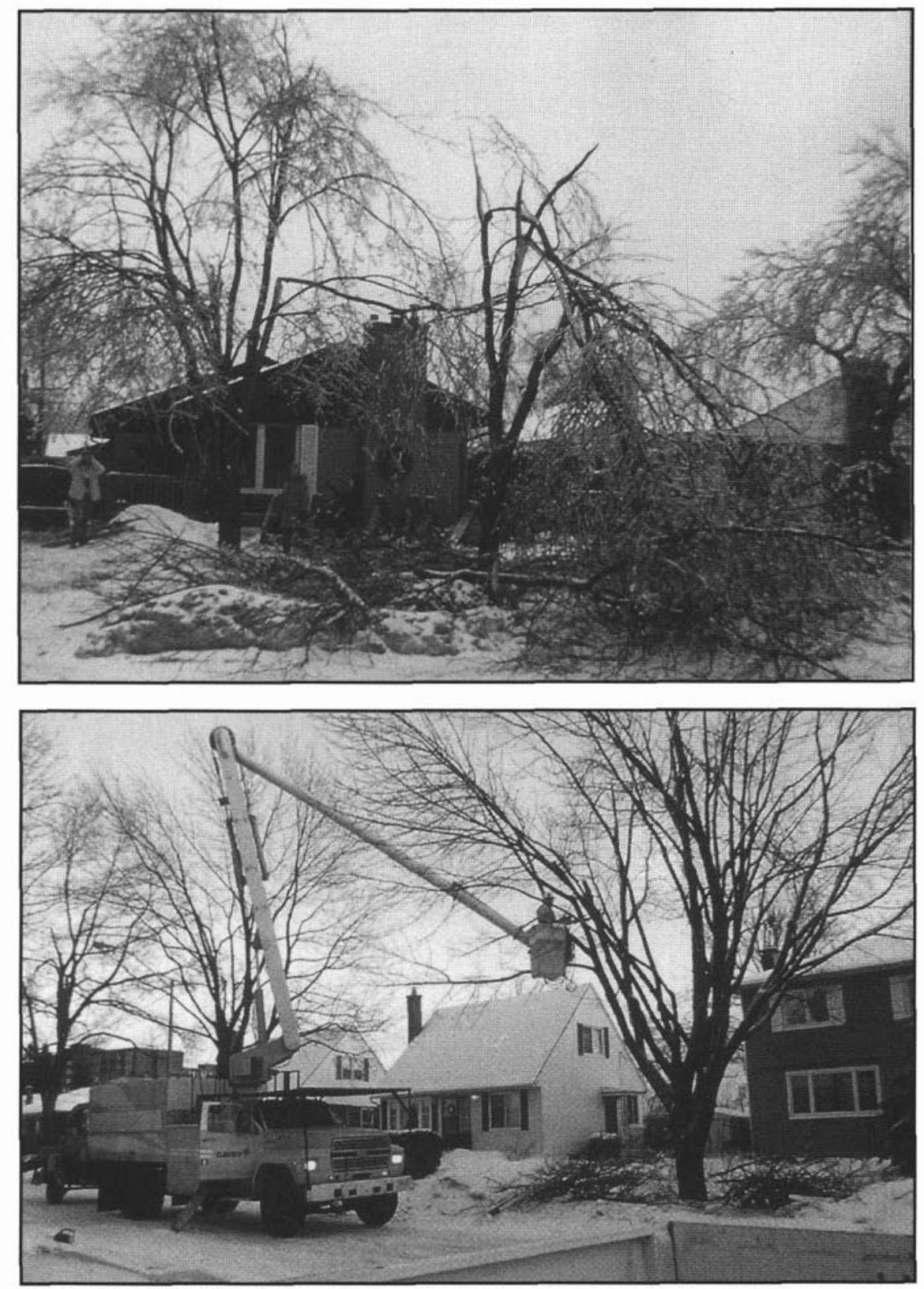

Photos by Brian Smith, City of Ottawa Arborist.

ronmental value. The cost to restore these assets must be evaluated as part of the overall cost of this storm.

Ultimately, the trees and forests of the National Capital Region, and in other areas of Eastern Ontario and Western Quebec, are key to its scenic beauty and contribute significantly to its economic and ecological well-being. More than ever, we need to work together to plan and act in ways that will restore our treasured image.

Recovery from this storm will require an interdisciplinary team approach. Our associations are ready to participate. Please do not hesitate to call upon us: Nelson Edwards, Councilor, Ontario Association of Landscape Architects, Ph: (613) 239-5057; Randy Lidkea, Executive Director, International Society 463-2316; John McNeil, President, Ontario Shade Tree Council, Ph: (905) 3368552; John Ebbs, Executive Director, Ontario Professional Foresters Association, Ph. (905) 764-2921. of Arboriculture - Ontario, $\mathrm{Ph}$ : (888) 


\section{Tempête de verglas La forêt privée dévastée}

La forêt privée du Québec souffrira profondément des effets de la tempête de verglas pour les prochaines années et les dommages influenceront les ac tivités des producteurs de bois et de sirop d'érable. Le territoire touché s'étend de l'Outaouais jusqu'à la Beauce, en passant par les Basses Laurentides, la Montérégie, l'éstrie et les Bois-Francs. Dans certaines régions, presque toute la forêt a été endommagée.

Une évaluation sommaire des dommages a été entreprise par le ministère des Ressources naturelles du Québec (MRN) afin de préciser l'étendue et l'ampleur des dommages et en vue de mettre en place les mesures d'aide nécessaires. Selon les données météorologiques d'Environnement Canada, la zone de verglas couvre près de 5 millions d'hectares où les précipitations et les accumulations de glace ont dépassé 30 millimètres, pour atteindre plus de 90 millimètres dans certains secteurs "du triangle de glace".

\section{Des milliers $d$ 'hectaches touchés}

Plus précisément, 2,4 millions d'hectares de forêts endommagées ont été classés selon une échelle des dommages variant de léger, à modéré et sévère. Le recoupement des zones météo de la tempête de verglas avec les cartes forestières permet d'évaluer que 320000 hectares d'érablières et 856000 hectares d'autres forêts feuillues sont susceptibles d'avoir été touchés. En moyenne, $80 \%$ du territoire affecté est du domaine de la forêt privée.

L'inventaire sommaire des dommages causés à la forêt québécoise a débuté dès le 14 janvier et pourra être complété au début du mois de février. Des lignes de virées aériennes ont été établies à tous les 2 kilomètres dans les secteurs les plus affectés. La sévérité des dommages varie grandement selon l'intensité des précipitations de verglas, la topographie, la composition des peuplements, leur orientation relativement aux vents du nord-est et l'historique sylvicole.

Le MRN a également mis sur pied un service téléphonique sans frais destiné aux propriétaires de boisés afin de les mettre en contact avec les spécialistes du Ministère quant aux mesures à prendre ainsi qu'aux méthodes d'intervention à privilégier selon les différentes situations. Les agents techniques du MRN et du ministère de l'Agriculture, des Pêcheries et de l'Alimentation du Québec (MAPAQ)

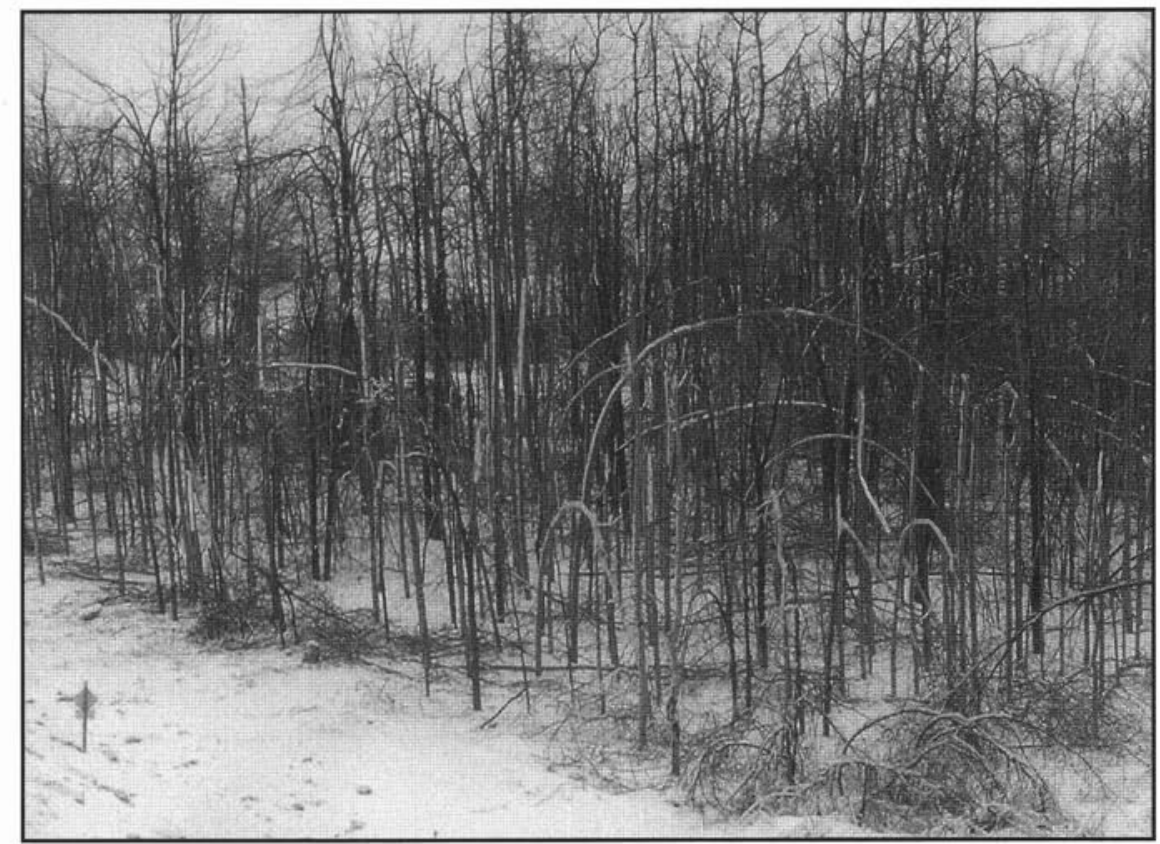

La Terre de chez nous. Selon les données météorologiques d'Environnement Canada, la zone de verglas couvre près de 5 millions d'hectares dans le sud-oust du Québec. Photo: Victor Brunette

en sont à évaluer une méthodologie pour évaluer les boisés touchés.

Selon une évaluation faite par des conseillers forestiers, toutes les classes d'âge ont été affectées, surtout dans le secteur du "triangle de glace". Les peupliers, bouleau blanc, bouleau gris et pins gris sont cassés. Très peu d'érablières ont été épargnées avec plus de $75 \%$ des cimes affectées. Les épinettes ont mieux supporté le verglas, mais les pins sont touchés. Dans les zones moyennement affectées, c'est-à-dire où de 25 à $50 \%$ des cimes est touché, le cèdre et la pruche ont subi de forts dommages tandis que dans les zones précommerciales, $60 \%$ des tiges est affecté.

Parmi les actions prévues, les différents partenaires de la forêt privée diffuseront sous peu des informations techniques sur les soins à apporter aux forêts, que ce soit en matière de coupes d'assainissement ou de programmes de récupération du bois perdu, de reboisement et de travaux sylvicoles appropriés là où ils seraient nécessaires. Enfin, pour les producteurs les plus affectés, des mesures de compensations financières devront être envisagés par l'État.

\section{Références utiles}

Hydro-Québec. Dégagement du réseau de distribution, réactions des arbres et norme d'élagage d'Hydro-Québec, Direction distribution, service de construction, maintenance et véhicules, mai 1993.

Lamontagne, Jean. S.O.S. verglas, Jean Lamontagne Consultants en arboriculture, lamontagarbre@mercure.net.

Ministère de l'environnement. L'élagage - la taille des arbres d'omement, Collection mission du paysage, $3 e$ édition revue et augmentée.

Ministère des ressources naturelles. La forêt sous le verglas: prudence et patience, Avis d'un comité ad hoc en recherche forestière et acéricole, janvier 1998.

Pin, Daniel. L'exploitation du chablis. Cours de formation, Silve Consultant, Saint-André-Avellin, juillet 1996.

Szaraz, Gérald. Reconnaissance sommaire de l'impact du verglas sur la forêt privée du point de vue des organismes de gestion en commun. RESAM, 23 janvier 1998.

par Victor, Brunette, ing. $f$.

Directeur général

Fédération des producteurs de bois du Québec 


\section{Sleet Storm lays private forests to waste}

Private forests in Quebec will take years to recover from the effects of the recent sleet storm. And the damage to forested areas will affect the activities of private woodlot owners and maple syrup producers. The area hit by the storm extends south-east, from the Outaouais to the Beauce region and includes the lower Laurentians, the Monteregian Hills, the Eastern Townships and Bois-Francs region east of Montreal. In certain regions, the storm damaged nearly all forested areas.

The Quebec Ministry of Natural Resources (MRN) conducted a cursory assessment in order to determine the extent and scope of the damage and organise appropriate support measures. Meteorological data compiled by Environment Canada indicated that the sleet storm zone covered approximately 5 million hectares on which precipitation and ice accumulation exceeded 30 millimetres, reaching 90 millimetres in certain sectors of the "ice triangle."

\section{Thousands of hectares damaged}

More specifically, some 2.4 million hectares of forests suffered light-to-moderate and severe damage. Overlaying meteorological maps of the sleet storm on forest maps shows that in all likelihood 320,000 hectares of sugar bush forest and 856,000 hectares of other hardwood forests were affected. Furthermore, 80 percent of this area is private forest land.

The summary assessment of the damage to Quebec forests began on January 14 and could be completed by the end of February. Aerial observation lines were established every two kilometres in the most severely affected areas. The extent of the damage varies greatly depending on the level of precipitation and topography as well as on stand composition and orientation with respect to northeast winds and silvicultural history.

The MNR also set up a toll-free telephone system for private woodlot owners to facilitate contact with Ministry specialists regarding the steps to be taken and intervention strategies according to the various situations they faced. Field advisors from the MRN and the Ministry of Agriculture, Fisheries and Food (MAPAQ) are presently developing a procedure to

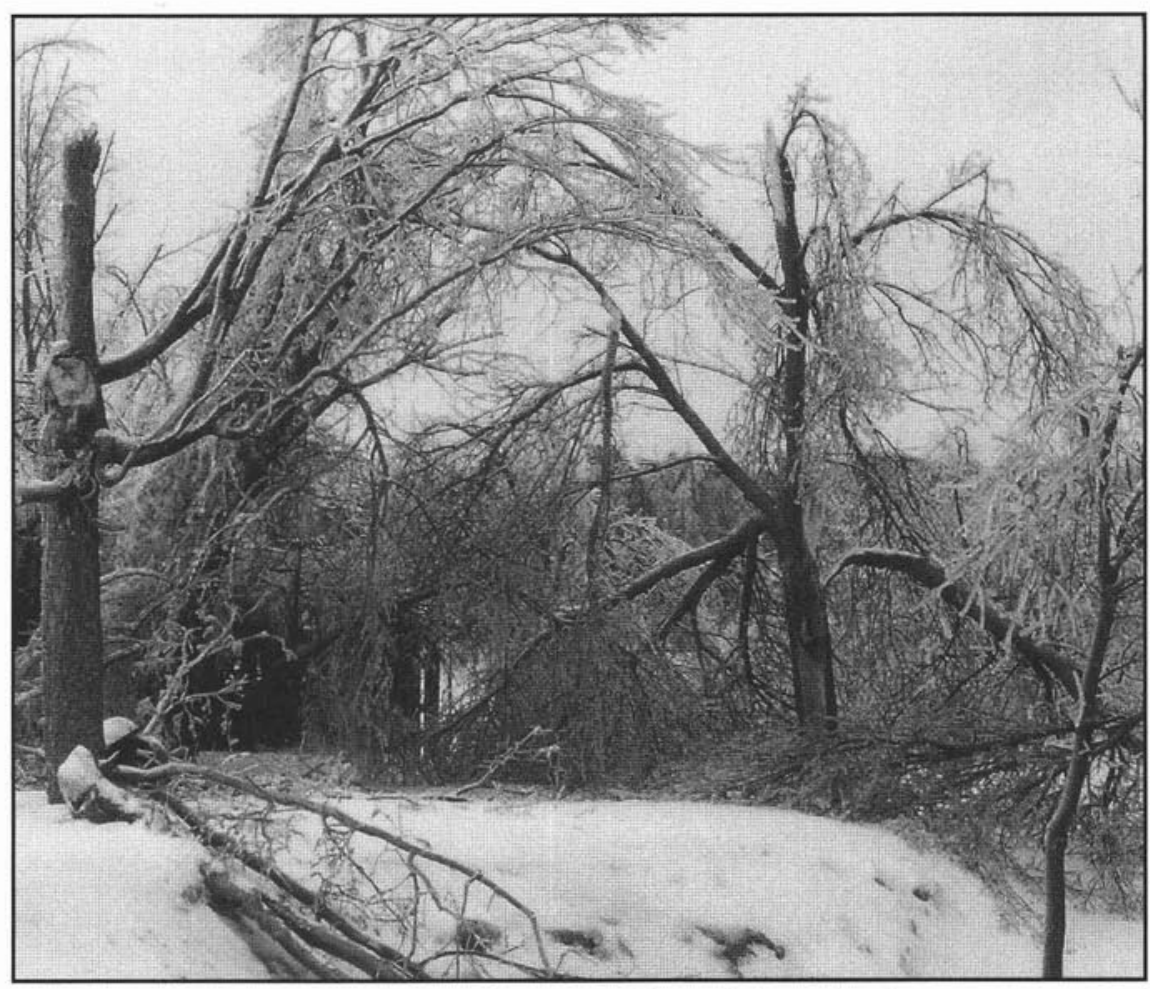

According to Environment Canada meteorological data, the sleet storm covered nearly 5 million hectares in southwestern Quebec. (Photo by H. Babcock).

calculate the damage to affected woodlots.

Forestry consultants have determined that all age classes were affected, particularly within the "ice triangle". Poplar, white birch, old field birch and jackpine trees have cracked. Few sugar bushes were spared; damage affected 74 percent of tree crowns. Spruce proved to be the most resistant, but pine suffered greatly. In moderately affected areas, that is, those where 25 to 50 percent of the crowns were affected, cedar and hemlock were severely damaged whereas 60 percent of the crowns in precommercial areas were also affected.

Various private forest organizations will shortly publish technical information on the care of affected forests: sanitation cutting, salvage cutting, reforestation or silvicultural treatments, as appropriate. Finally, the government will look into financial compensation measures to help the most severely affected forest owners.

\section{Useful References}

Hydro-Québec. Déménagement du réseau de distribution, réactions des arbres et norme d'élagage d'Hydro-Québec. Direction distribution, service de con- struction, maintenance et véhicules, May 1993.

Lamontagne, Jean. S.O.S. verglas. Jean Lamontagne, Arboriculture Consultants. E-mail: lamontagarbre@mercure.net. Ministère de l'Environnement. L'élagage - La taille des arbres d'ornement. Collection mission du paysage, 3 rd ed., revised and augmented.

Ministère des Ressources Naturelles. $\mathrm{La}$ forêt sous le verglas: Prudence et patience. Bulletin prepared by an ad hoc forestry and maple cultivation research committee, January, 1998.

Pin, Daniel. L'exploitation du chablis. Cours de formation. Silve Consultant, Saint-André-Avellin, July 1996.

Szaraz, Gérald. Reconaissance sommaire de l'impact du verglas sur la forêt privée du point de vue des organismes de gestion en commun. RESAM, January 23 , 1998.

by Victor Brunette, ing. $f$.

Executive Director

Fédération des producteurs de bois du Québec 

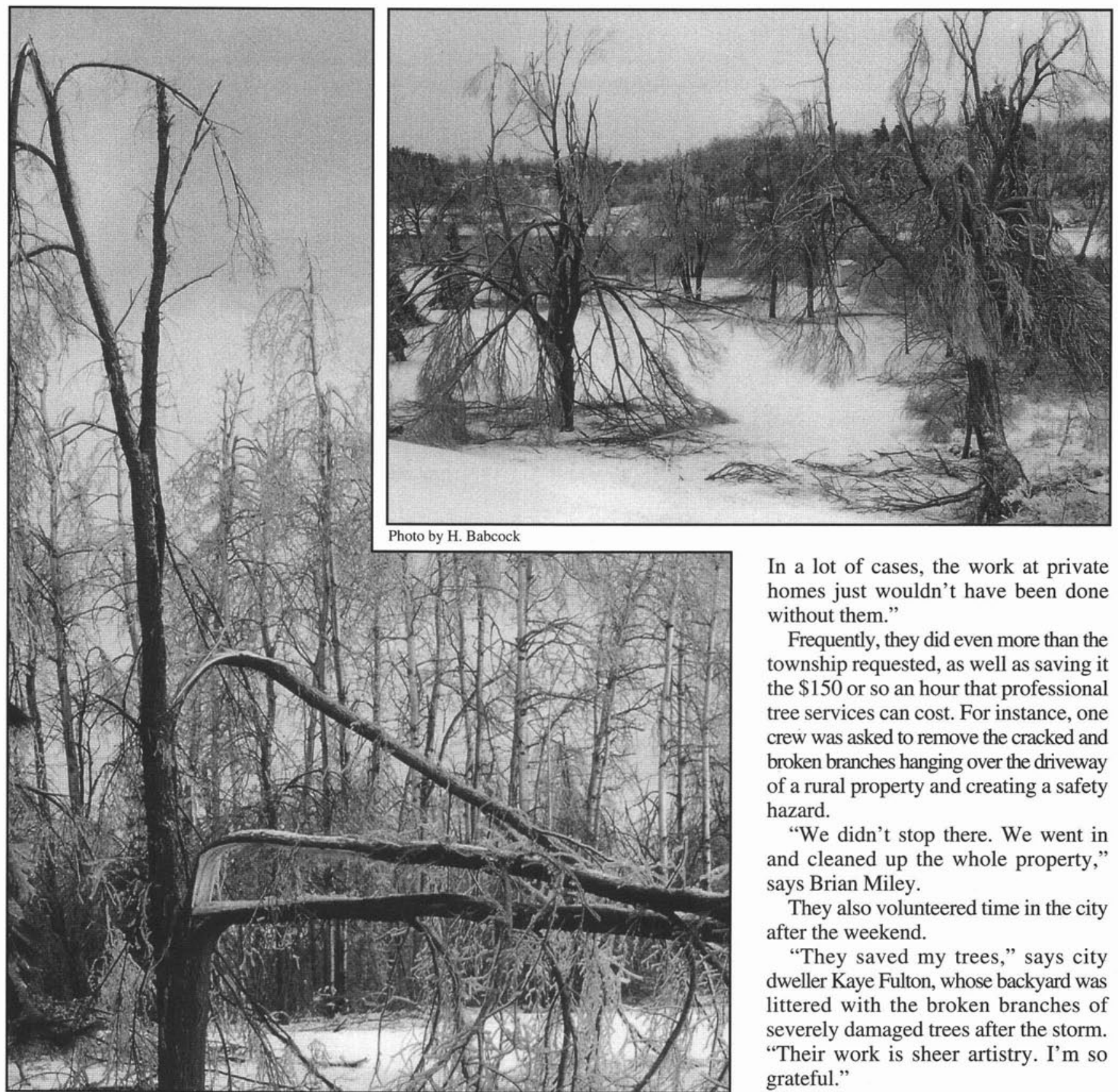

\section{First Nations Native Arborists Help Save Shattered Trees}

Not many workers offer their services free after their contract is over. Yet this is just what $\mathrm{Al}$ and Brian Miley and their work crews are doing.

The two brothers, Ojibways from the Mississauga Reserve in the Algoma District of Northern Ontario, own separate tree service business. After completing their paid work climbing, prun- ing and preserving trees damaged by the January ice storm, they "decided to stay to fill in as volunteers, because there was so much to do.

"They just called us and asked us what we needed done," says Shelley Goertzen, deputy clerk of the Township of Goulbourn, an area hard hit by the storm. "And they did a fabulous, bang-up job.
In a lot of cases, the work at private homes just wouldn't have been done without them."

Frequently, they did even more than the township requested, as well as saving it the $\$ 150$ or so an hour that professional tree services can cost. For instance, one crew was asked to remove the cracked and broken branches hanging over the driveway of a rural property and creating a safety hazard.

"We didn't stop there. We went in and cleaned up the whole property," says Brian Miley.

They also volunteered time in the city after the weekend.

"They saved my trees," says city dweller Kaye Fulton, whose backyard was littered with the broken branches of severely damaged trees after the storm. "Their work is sheer artistry. I'm so grateful."

"It gives you a good feeling to be able to help," says Al Miley. "And it's something positive about First Nations people that might have a ripple effect for all First Nations."

"We just wanted to help."

The Miley brothers intended to absorb the overtime costs for the 13 members of their work crews - all Ojibways from the same reserve except for one Newfoundlander, Bob White. "But we didn't have to sponsor them," they said. "One after another volunteered their time. None of the men would take any money."

Ottawa Citizen 


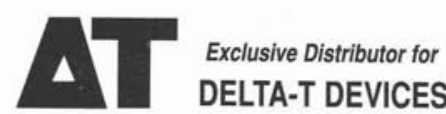 \\ DYNAMAX \\ Exclusive Distributor for \\ The Source For Electronic Plant \& Environment Monitoring}

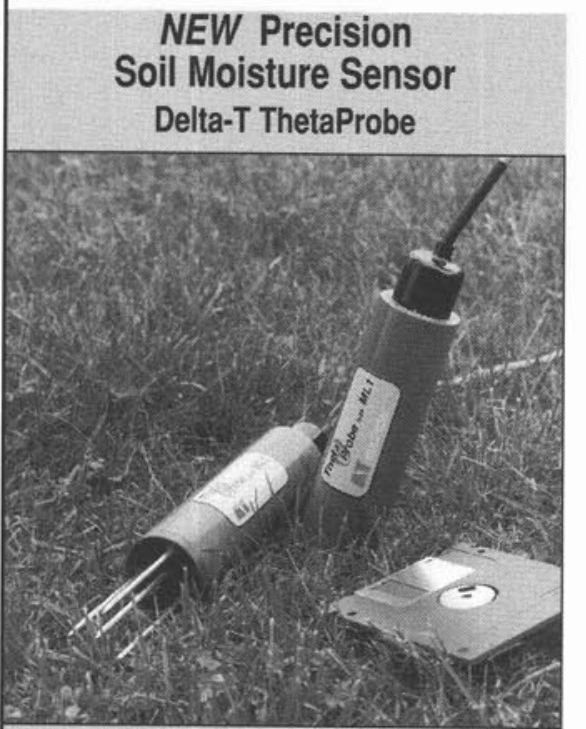

- Accuracy to within $\pm 2 \%$ volumetric

- Direct connection to virtually any datalogger

- For burial or portable application

- Minimal soil disturbance

- Easy calibration for particular soil types

- New precision method that measures

dielectric constant from microwave signals

NEW Canopy Analysis System Sunscan

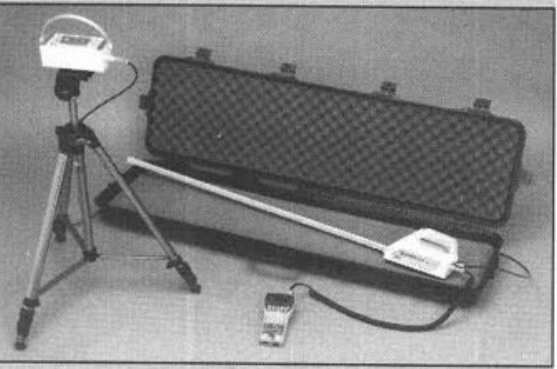

- Measurement of incident and transmitted PAR in plant canopies

- Optional Beam Fraction sensor to measure direct and diffuse fractions of incident light above canopy

- Direct calculation and display of Leaf Area Index (LAl)

- Extensive data storage and analysis

- Easy to use, portable and weatherproof

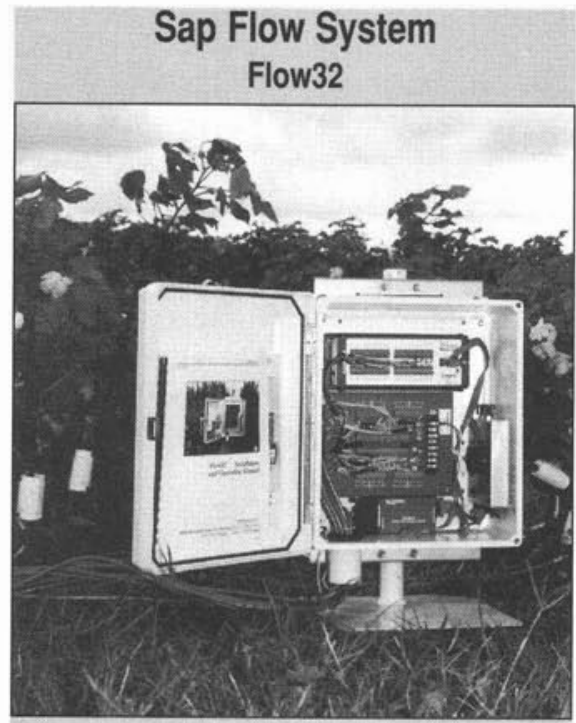

- Monitor up to 32 plants per system

- Datalogger, automatic data retrieval

- Real-time Sap Flow with graphics

- Fully portable, fully assembled

\section{Soil Moisture System VADOSE TDR}

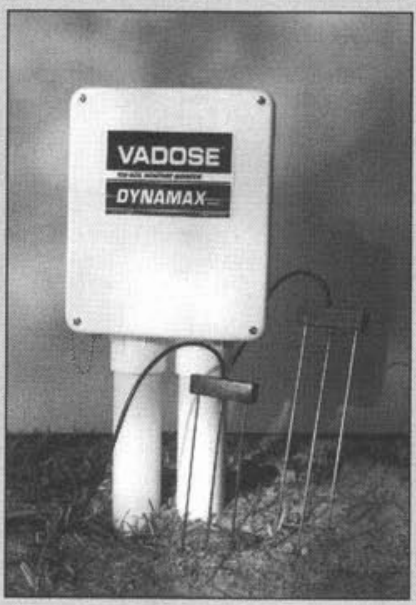

- Soil moisture and conductivity

- Accurate, interactive analysis

- 16 input multiplexer

- Logs data, analyses wave forms

- Long-term measurement capability

- Weatherproof, rugged for field study
Photosynthesis Systems LCA4 with Leaf Microclimate Control

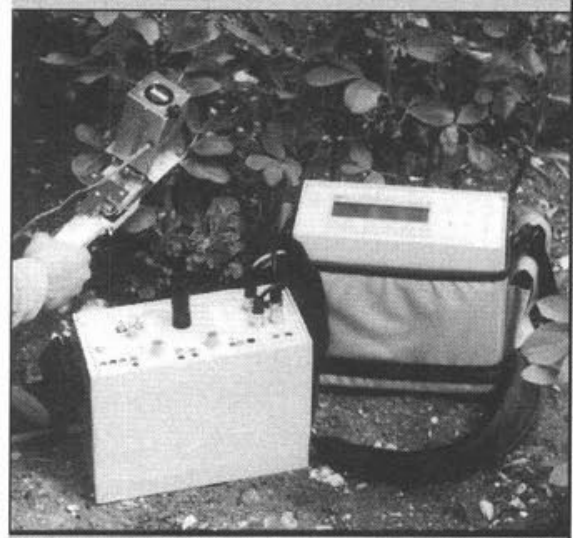

- $\mathrm{CO}_{2}$ and $\mathrm{H}_{2} \mathrm{O}$ infared gas analysis

- Lightweight, $4.5 \mathrm{~kg}$, easily portable

- Accurate and reliable

- 7 hour battery life (Optional 20 hour)

- Broad, narrow or conifer plant leaf chambers

- Automatic control of $\mathrm{CO}_{2}, \mathrm{H}_{2} \mathrm{O}$, P.A.R. and temperature

- Above and below ambient $\mathrm{CO}_{2}, \mathrm{H}_{2} \mathrm{O}$, P.A.R. level to $2300 \mu \mathrm{mol} \mathrm{m} \mathrm{m}^{-2} \mathrm{~s}$

- All variables logged on PCMCIA memory card

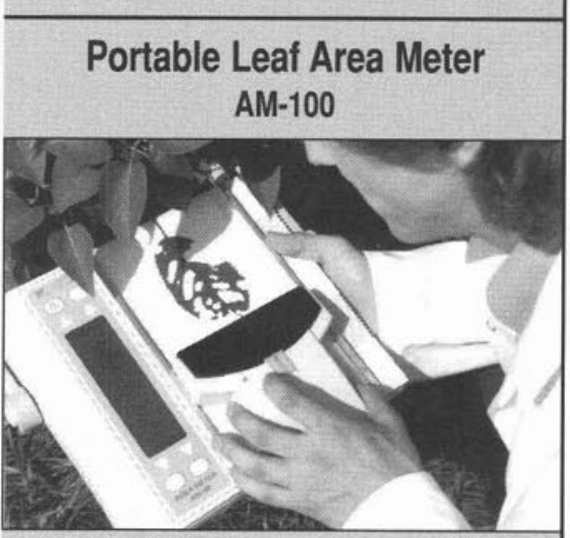

- Suitable for discolored and diseased leaf application

- Large graphical display

- Non destructive

- Leaf area and associated parameters

- User friendly, flexible field operation

- Integral data and image storage

For a FREE BROCHURE, Prices or Questions, call our application HOTLINE 1-800-727-3570

\section{DYNAMAX, ING.}

